\title{
Troubles ahead
}

\section{The outcome of the UK election leaves science challenged on at least three fronts.}

It's customary for scientific leaders to complain, before, during and after national election campaigns, that science and technology policy issues have been 'ignored' by the political class.

Let's hope they'll draw some comfort, then, from what happened last month in Britain: in the run-up to the 7 May general election, many critical policy issues - including energy, industry, defense and housing - were largely ignored.

This election campaign was, instead, mostly about 'politics' - who might partner with whom, in a coalition government that, the polls and pundits claimed, was the election's inevitable result. On 8 May, the country woke up with a majority, Conservative government, and realized that there had been virtually no discussion of what such a government's policies might be.

The one exception to that had been the clear promise of Conservative Prime Minister David Cameron to hold an in/out referendum on British membership of the European Union by 2017.

Cameron's newly elected government is theoretically committed to deep reductions in public spending. However these commitments were made mainly to entrap the opposition Labour Party; Cameron's government doesn't now need to deliver on them. It is, in fact, anyone's guess whether it will now continue down the path of making real, deep cuts in departmental spending - or cut benefits for the poor, and quietly maintain spending elsewhere.

That's why the financial outlook for research in Britain is now so uncertain. In the campaign, both main parties restated their general commitment to science, but refrained from making any specific pledge to exempt it from spending cuts. (For the past decade, under Labour- and Conservative-led governments, the UK science budget has been 'ring-fenced' and protected from cuts imposed on other programmes ${ }^{1}$.)

Therefore the science budget is theoretically open to cuts of as much as $20 \%$, over the next three years, which is what the government's official spending projections would require of non-protected programmes. However, it is unlikely that such deep cuts will materialize.

That is partly because George Osborne, the chancellor of the exchequer (finance minister) appears to take a shine to science

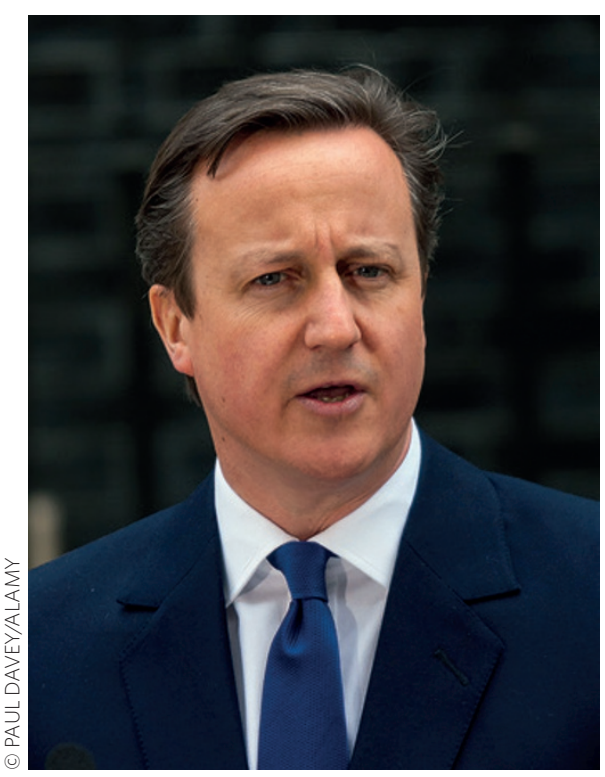

It has been suggested, for example, that UK universities take direct responsibility for the physical return of overseas students to their homelands. In this and other regards, the UK is moving in exactly the wrong direction. There's a stark contrast with the United States, which, despite its own immigration issues, remains resolutely receptive to employing highly skilled students, trained at its own institutions.

It was concern about immigration that prompted Cameron's promise of an EU referendum. The conventional wisdom is that Britain will vote to stay in the EU. But the narratives of referenda are notoriously difficult to control. And the Prime Minister's apparent strategy - promising to renegotiate Britain's EU membership, almost certainly failing to do so, but then declaring success ahead of the vote - seems implausible. There remains a strong outside chance that the UK will, by accident or design, vote to leave the EU.

Research, in the shape of Horizon $2020^{3}$, is and technology. As chancellor in the last government, Osborne didn't achieve the 'rebalancing' of the British economy that he said was required, after the 2008 economic crash. But the progress he did make involved the so-called Golden Triangle (Cambridge, Oxford and London), where world-leading universities are helping to ferment successful, high-technology businesses.

It's a bit of a thin story, but the only one in town - and Osborne isn't about to trample all over it by imposing draconian cuts on these elite institutions. He may be more inclined to heed calls from the new science and universities minister, Jo Johnson - a former Financial Times journalist and younger brother of Boris Johnson, the mayor of London - to protect science from the worst of the cuts.

That would still leave UK research facing two major challenges. Both spring from the single policy issue that did feature prominently in the election campaign - immigration.

Fixation on the immigration issue is already having widespread, unintended consequences at UK universities ${ }^{2}$. Basically, Britain has got into the habit of setting arbitrary targets for net immigration (100,000 a year, Cameron said in 2010), and then missing them $(298,000$, at the last count). As a result, increasingly arbitrary and bizarre immigration controls are being put in place, hampering the recruitment and retention of talented overseas students and staff. the only major EU spending area from which Britain gets more out than it puts in. In 2013, for example, the last year for which data is available, the UK got $€ 1.11$ billion out of the $€ 9.6$ billion allocated under Framework 7, its predecessor programme. That's almost the same as Germany ( $€ 1.14$ billion), which has a much larger economy, and far more than any other EU member state.

Exclusion from Horizon 2020, or even some form of associate membership, would be a huge step backwards for British science. The recent experience of Switzerland - which stands on the brink of exclusion from Horizon 2020, after a referendum there placed caps on immigration - seems to dispel the idea that UK research could retain its links to EU programmes, if Britain left the EU. A group called Scientists for EU is already organizing to put forward the scientific case for Britain to remain inside it (see http://scientistsforeu.uk).

At the same time - unsure, as it must be, of Osborne's real intentions - the research lobby is gearing up to vigorously oppose spending cuts at the universities. The scientific community may have been a bystander during the election campaign, but for the next year or so, it had better be in the thick of the action.

\footnotetext{
References

1. Nature Mater. 9, 603 (2010).

2. Nature Phys. 10, 891 (2014).

3. Nature Mater. 11, 477 (2012)
} 